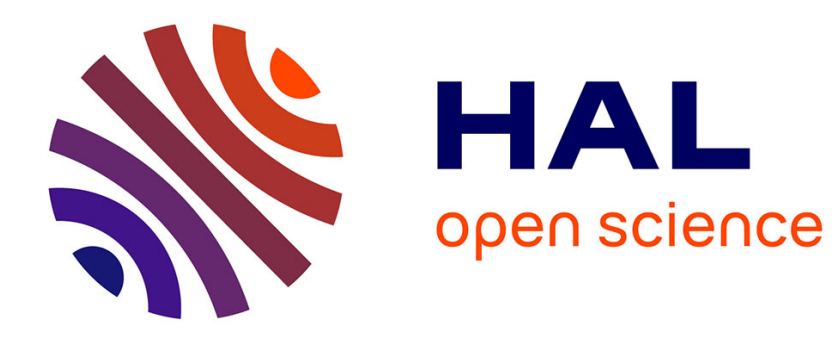

\title{
Drug trafficking in and out of the Golden Triangle Pierre-Arnaud Chouvy
}

\section{To cite this version:}

Pierre-Arnaud Chouvy. Drug trafficking in and out of the Golden Triangle. An Atlas of Trafficking in Southeast Asia. The Illegal Trade in Arms, Drugs, People, Counterfeit Goods and Natural Resources in Mainland, IB Tauris, p. 1-32, 2013. hal-01050968

\section{HAL Id: hal-01050968 https://hal.science/hal-01050968}

Submitted on 25 Jul 2014

HAL is a multi-disciplinary open access archive for the deposit and dissemination of scientific research documents, whether they are published or not. The documents may come from teaching and research institutions in France or abroad, or from public or private research centers.
L'archive ouverte pluridisciplinaire HAL, est destinée au dépôt et à la diffusion de documents scientifiques de niveau recherche, publiés ou non, émanant des établissements d'enseignement et de recherche français ou étrangers, des laboratoires publics ou privés. 


\section{Atlas of Trafficking in Mainland Southeast Asia}

\section{Drug trafficking in and out of the Golden Triangle}

Pierre-Arnaud Chouvy

CNRS-Prodig

(Maps 8, 9, 10, 11, 12, 13, 25, 31)

The Golden Triangle is the name given to the area of mainland Southeast Asia where most of the world's illicit opium has originated since the early 1950s and until 1990, before Afghanistan's opium production surpassed that of Burma. It is located in the highlands of the fan-shaped relief of the Indochinese peninsula, where the international borders of Burma, Laos, and Thailand, run. However, if opium poppy cultivation has taken place in the border region shared by the three countries ever since the mid-nineteenth century, it has largely receded in the 1990s and is now confined to the Kachin and Shan States of northern and northeastern Burma along the borders of China, Laos, and Thailand.

The Golden Triangle is not only an isolated mountainous and heavily forested area overlapping the contiguous and outlying border areas of three countries, it is also populated by many extremely diverse ethnic groups, many of them tribal and semi-nomadic slash-andburn agriculturalists. In fact, the international borders of Burma, Laos, and Thailand also cut across two zones that are intricately woven together: the Tai linguistic zone, composed of Shan, Thai, and Lao peoples, over which is superimposed a more complex zone of numerous other ethnic groups that are dispersed throughout the tri-border area and in neighbouring China. The "Golden Triangle" expression was first coined by the United States ViceSecretary of State Marshall Green during a press conference on 12 July 1971. Referring to a polygon whose angles could be found in Burma, Laos, and Thailand, where opium production was indeed concentrated, Green implicitly acknowledged - and probably rightly 
so - the absence of large-scale commercial opium production in China. This exclusion was all the more necessary as it was made three days prior to the announcement by President Nixon of his February 1972 official visit to the People's Republic of China, the first visit of a United States President to Communist China (Renard, 1996: 4).

In addition to being a politically-grounded geographic reference, the expression "Golden Triangle" also refers to one of the region's most important economic features. "Golden" refers to opium production and trade, which developed considerably in mainland Southeast Asia over the course of the second half of the twentieth century. According to the Swedish journalist and veteran Burma-watcher Bertil Lintner, the first traders of the triborder region, especially those of the Thai-Burmese border towns of Mae Sai (Thailand) and Tachileck (Burma), exchanged the precious substance for 99 per cent pure gold ingots (Lintner, 1994), hence the name.

Opium production in mainland Southeast Asia has always been concentrated in the tri-border region, in the mountainous borderlands of Burma, Laos, and Thailand, where rugged hills and mountains, heavy monsoon rains, and lack of transport infrastructures have long protected rebel armies and illicit crops from the writ of central governments and antidrug agencies. Ron Renard describes how the region has been favourable to the Golden Triangle's emergence: "The contraband trade in narcotics flourished all the more because the region's imposing terrain and rivers remain untamed by roads and bridges. The annual monsoon rains thus render the area even more inaccessible for several months each year" (Renard, 1996: 5). After decades of the expansion of poppy cultivation in the three countries, opium production has progressively receded, almost completely disappearing from Thailand in the 1990s, and seriously decreasing in Laos during the early 2000s. Poppy cultivation has abated, concentrating in northern and north-eastern Burma, where it had come from in the mid-nineteenth century. Although Burmese opium production has also considerably 
decreased after 1998, it has nevertheless proven to be geographically and historically resilient. Burma's turbulent political history since its independence in 1948 can obviously be held responsible for Asia's longest illicit opium production: the opium economy and the war economy have clearly nurtured one another in a country that has suffered an internal war for the past sixty years and where the world's longest armed insurgency still takes place ${ }^{1}$. Indeed, as an extremely valuable economic resource opium has often enabled warring factions to fund their respective war efforts. Opium production has also weighed upon strategic negotiations, offering both state and non-state actors opportunities to gain political leverage or create ad hoc strategic alliances. For instance, the Burmese junta has very early and repetitively integrated opium in its negotiation strategy so as to affect power struggles, something that some anti-government forces have directly or indirectly benefited from. Indeed, "according to the account of Chao Tzang, Olive Yang [who dominated the opium trade in Kokang from the end of the Second World War until the early 1960s] 'had been permitted by the Burmese to engage in opium trade in exchange for keeping out the KMT', 2 , until "1962 when the Burmese army occupied Kokang and arrested her and her brother, Edward Yang, the Kokang Prince” (Renard, 1996: 56).

\section{The old drug trafficking routes of Mainland Southeast Asia}

Since the emergence of the Golden Triangle, opiate trafficking followed the main caravan axes of Southeast Asia and Southern China. Indeed, Chinese opium was already exported to Southeast Asia at the end of the nineteenth century, when Chinese production amounted to double of the imports forced onto the Middle Empire by the British. Also, the Haw, the Hmong and the other tribal populations who migrated from China to Southeast Asia, played an important role in spreading opium production in the Indochinese peninsula, and had a significant impact on the emergence of the Golden Triangle by perpetuating a few 
trafficking and contraband routes. The caravan tracks of the Haw, which crisscrossed Siam very early, largely contributed in turning Thailand into a privileged hub of heroin trafficking. Mya Maung (Mya Maung, 1991) described the diverse commercial routes that feed Burma's black market from Thailand, China, and India. Mae Sai, Mae Sot, and Ranong, respectively in northern, western, and southern Thailand, have long been the main crossborder towns along Burma's eastern border. Most of the trade occurring between Burma and Thailand used to happen between Tachileck and Mae Sai until cross-border commerce started being disrupted by ethnic rebellions and Communist guerrilla activities. Present-day trading routes, whether legal or illegal, are basically the same that the Burmese previously used to invade and raid Siam (in the sixteenth and eighteenth centuries for example). The passage from Moulmein to Myawaddy and Mae Sot is one of the most famous such invasion routes. In a similar way, the route followed by the Mongols when they invaded Burma in the thirteenth century has long been the main trading route between Burma (Muse) and China (Ruili): the so-called Jade Road was developed at the end of the seventeenth century by Yunnanese merchants and would only be known as the Burma Road during the Second World War. The Jade Road developed in order to export the highly-coveted and extremely expensive imperial green jade (jadeite) from Kachin State to China, where it is still highly prized (Mya Maung, 1991: 210-215; Walker, 1995, Frey, Lintner, 1995, Levy, Scott-Clark, 2002). The Jade mines are located in Hpakant, in Kachin State, but after the Chinese Communist revolution its trade was diverted from China to Thailand, through Mae Sai and on way to Hong Kong, which quickly became the world's most important trading town for green imperial jade. It was not long, however, before Hong Kong turned into one the world's main heroin hubs.

Thailand can be said to be the traditional outlet of Burmese opium and heroin and has long been the main outlet in Southeast Asia, at least since the emergence of the Golden 
Triangle as such, and until Laos and China started draining increasing amounts of Burmese opiates towards Hong Kong, Macao, or Vietnam. After the post-Second World War emergence of the Golden Triangle there were in fact two main routes that we can henceforth consider as "traditional" because they were very much affected by the historic and geopolitical evolutions of Southeast Asia, and because they were more or less replaced by new routes. The first was an air route and has largely disappeared as of today. The second, a ground route, changed very recently and is at present of decreased importance. As for other routes which were once of minor importance, they have since been recently, and profoundly, modified.

In his seminal work of reference on "The politics of heroin in Southeast Asia" (1972) historian Alfred McCoy has shown how the secret wars and covert operations carried in Laos and in Vietnam by the French, and then by the United States, spurred opium and heroin trafficking at regional and global levels. He revealed the role played by the CIA and one of its airline companies, Air America, which had taken over in 1965 from the French network of Corsican airmen, in the anti-Communist war effort of the United States as well as in the spread of heroin addiction among their own troops fighting in Vietnam. Air America, Continental Air Service, and Lao Development Air Service transported opiates from the Long Tieng and Vientiane airports in Laos - where the heroin was supplied by Hu Tim-heng, a partner of General Ouane Rattikone, one of Laos' major opium traders and the commander in chief of the Laotian Army between 1965 and 1971 - to Saigon. In Vietnam, the wellconnected Ma brothers dealt with the Vietnamese Air Force's Vice-Marshal Ky. Later, it was General Dang Van Quang, the intelligence adviser to Vietnamese President Nguyen Van Thieu and the commander in chief of the Vietnamese navy, who took over opiate trafficking from Cambodia to South Vietnam and Hong Kong (McCoy, 1991: 226-234; Booth, 1999: 198). 
Always in the context of its anti-Communist efforts, the CIA played a significant role, although an indirect one, if not in north-eastern Burma's opium production, then at least in the organization of its commerce by the KMT troops which it supported in its fight to take China back from the Communists. The vast majority of the opium traded from Burma to Thailand or Laos was conducted by the KMT troops, secretly supported by the CIA after their flight from southern China to Burma's Shan State. The caravans that transported the Burmese opium, under control of the KMT troops, were largely made of Panthay and Haw caravaners whose mules and networks allowed such traffic in the hills and mountains of eastern Burma and western Thailand. After the 1967 "opium war" that led to the defeat of Chan Shi-fu, alias Khun Sa (1934-2007) ${ }^{3}$, in Ban Houay Xay, Laos, the KMT - according to the CIA operative William Young - controlled about 90 per cent of Burma's opium trade from its bases in northern Thailand, while the Shan caravans then only transported approximately 7 per cent of Burma's opium and those of the Kachin Independence Army (KIA), which were mostly loaded with green imperial jade, 3 per cent (Booth, 1999: 198).

The KMT established itself in the north of Thailand after its Mong Pa Liao headquarters, along Burma's Mekong bank, were attacked by five thousand soldiers of the Burmese Army and twenty thousand Chinese Communist troops, in January 1961. The nationalist troops first fled to Luang Namtha province in Laos. But their repatriation to Taiwan, organized by the US Department of State whose embarrassment was all the more important that its support to the KMT had been made public, was organized via Thailand. Many of them, however, stayed in Luang Namtha until 1962, before they settled down permanently in Thailand, along Burma's border (in Mae Salong - now known as Santikhiri for example). From that moment on, the KMT, which had been utilised by the CIA in its antiCommunist agenda, could play a similar role for and from Thailand while being in privileged geographical position to resume its drug trafficking activities. 
Thailand's history helps understand how the kingdom became the region's first heroin outlet after Second World War. First of all, Thailand has long been home to the world's largest community of Teochiu, or Chiu-Chao ${ }^{4}$, a Chinese diaspora from Swatow, in Guangdong. According to Sterling Seagrave, the son of the famed Burma Surgeon, the Teochiu constitute what is likely to be the most powerful and the richest of the world's underground networks (Seagrave, 1995). Forming probably one of the most fortunate of the overseas Chinese's networks, the Teochiu achieved a dominant economic position in Siam following the important political role that they played in the history of the Thai kingdom. In fact, in the Thai context of historic vassalage relations maintained with China, the role of economic adviser to the Thai monarchs had long been awarded to Chinese merchants and especially to Teochiu people. General Taksin (1734-1782), whose father was Teochiu, first assured the Teochiu a leading position in Siam's political and economic life by ennobling many of them after he reunited the kingdom which the Burmese had invaded in 1767. When Taksin the Great became king of Siam, in 1768, he moved the capital from Ayutthaya to Thonburi and the Teochiu advisers, whether noble or merchants followed him en masse.

Later, during the Second World War, the Teochiu managed to secure a monopoly over rice commerce, thereby affirming their economic influence over the Hokkien Chinese ${ }^{5}$ who, in spite of the fact that they were the world's most numerous and most dispersed of the overseas Chinese, had not allied themselves to the then occupying Japanese forces in Southeast Asia. This privileged position in the Thai politico-economic system also allowed four or five of the most important Teochiu syndicates to achieve a quasi-monopoly over the Golden Triangle's opium and heroin trafficking. Three leaders from some of the 1970s main Hong Kong-based Teochiu triads largely invested themselves in trafficking heroin from the Golden Triangle: Ma Sik-yu (alias White Powder Ma), Ma Sik-chun (Golden Ma), and Ng Sik-ho (Limpy Ho). Ma Sik-yu began trafficking heroin in 1967 and quickly gained direct 
access to the source supply, that is, to the Golden Triangle, where he made contact with KMT General Li Wuen-huan who successfully recruited him as an intelligence agent for Taiwan. Southeast Asian Teochiu triads, controlled by Ma Sik-yu, infiltrated the Communist groups of the region while considerably increasing their drug trafficking activities. Thailand therefore ended in the centre of the system, benefiting from the importance and the connections of the Teochiu community as well as its central geographic position. Laos was also included in this system after the Ma brothers allied themselves with General Ouane Rattikone who was supplying them with the infamous "999" or "Double UO Globe" heroin (Booth, 1999: 195-198). In truth, the Teochiu were somehow predestined to become the main suppliers of the Golden triangle's opium and heroin since one of their Siamese commercial associations had very early on obtained an official license for opium retail sales in Shanghai's French concession: the first opium retail store of Shanghai, Hongtai, was owned by Teochiu merchants.

Associated with Thai nationalism, irredentism, and militarism, these developments of the history of Siam, which became Thailand in 1937, facilitated the extraordinary importance of drug trafficking in the kingdom. During the Second World War, Thailand, supported by the Japanese, motivated by a rising Thai linguistic nationalism and nurtured by strong antiChinese feelings, annexed Burma's Shan States (where Tai languages are spoken, such as Shan). Kengtung became the headquarters of the Thai Northern Army (or Phayap Army), under the orders of General Phin Choonhavan ${ }^{6}$ who acted as the military governor of the Shan States. Phin was one of the actors of the 1932 coup d'état that eventually installed the Field Marshal Phibun Songkhram in power (1938-1944 and 1948-1957). Phin not only controlled the heart of what was not yet called the Golden Triangle; he also had privileged connections with some of the most powerful of Thailand's Teochiu syndicates. Another fundamental component of the Thai drug trafficking equation is the Japanese occupation of 
the region and the presence of some of the instigators of the Japanese Army's southern strike in Southeast Asia: the same who, while in the Japanese Guangdong Army, had been involved in the marketing of Manchuria's opium in eastern Asia. In the 1930s, Japan was already funding part of its Chinese military expeditions by producing and trading opium from Manchuria (Meyer, Parssinen, 1998: Seagrave, 1995; Kobayashi, 2000). During the Second World War, the Japanese traded low-grade heroin bought from the Chinese Nationalist government in order to finance their occupying army in Guangdong (Booth, 1999; Meyer, Parssinen, 1998; Seagrave, 1995). Naturally then, the Japanese Army had a direct interest in supporting the occupation of the Shan States by the Thai Northern Army and encouraged its commander, General Phin, to build durable and lucrative relations with the KMT.

Consequently, the role of the KMT in the development of the opium trade grew considerably. In China, the Japanese had established financial links with the Chinese nationalists and the Thai followed suit after General Phin met with General Lu Wi-eng, commander of the KMT's 93 ${ }^{\text {rd }}$ Division, in Yunnan, April 1944 (Seagrave, 1995). Five years later, when the Communist victory forced the KMT to flee to Burma, the $93^{\text {rd }}$ Division took refuge in Shan State, along with its new commander, General Li Mi. Thus the links that had been tied between the KMT and General Phin proved useful as the exiled KMT troops "seized control of the best opium-growing areas in the Golden Triangle, and resumed a lasting military and commercial alliance with General Phin in Thailand - all made possible by Japan's wartime effort” (Seagrave, 1995: 159-161).

After the war, and two years of democratic transition, Phibun and his military clique returned to power in Thailand. Phin was elevated to commander-in-chief of the armies, Marshal Sarit Thanarat became the commander of the First Army, thereby controlling Bangkok, and the son-in-law of Phin, General Phao Sriyanond, was made deputy director of the national police force. Phin, Phao and Sarit monopolized opium and heroin trafficking for 
years and turned Thailand into a regional drug-trafficking hub. Phin and Phao successfully won control of two of the five main Teochiu syndicates of Thailand that oversaw the large majority of the opiate trade: from northern Thailand down to Bangkok's warehouses, and all the way to Singapore or Hong Kong and Taiwan. After 1948, when Phin seized power and became Prime Minister, Sarit was made commander-in-chief of the armies and Phao directorgeneral of the police. Two rival camps formed and both men engaged in a fierce competition over opium and heroin trafficking.

Opiate trafficking became all the more important after the Shan State of Burma sheltered the defeated troops of the KMT. The $93^{\text {rd }}$ Division, now commanded by General Li Mi, had successfully appropriated some of the region's best opium lands and assured the transport of opium and heroin to Thailand where Teochiu syndicates, the Thai Army, and the Thai police - controlled respectively by Sarit and Phao - safeguarded the shipments to their final destinations. Twenty years after Chiang Kai-shek's KMT had shared the proceeds from the Green Gang's drug trade, during the 1930s in Shanghai, the Generalissimo and his son, General Chiang Ching-kuo, ordered General Li Mi to resort to drug trafficking in order to subsist in its rear base. The United States also played a notorious role in the development of the drug trade between Burma and Thailand: the CIA chose to favour the most eager of the two competing Thai camps and supplied Phao and his police force with about 35 million US dollars worth of equipment between 1950 and 1953. Through its front organization, known as Sea Supply Corporation, the CIA delivered its material aid not only to Phao and his police but also to the KMT: in fact, the CIA provided Phao's police with the modern equipment that Sarit and the Thai Army were denied, and Phao and the Thai police in return protected the military shipments that the CIA was also sending to the KMT to support its hopeless attempts at reconquering Yunnan and China (McCoy, 1991: 184). As Alfred McCoy explains: "Since Sea Supply shipments to KMT troops in Burma were protected by the Thai police, Phao's 
alliance with the CIA gave him extensive KMT contacts, through which he was able to build a virtual monopoly on Burmese opium exports" (McCoy, 1991: 184). However, in 1957, when General Sarit and his troops seized power from Phibun, Phao fled to Switzerland (where he died in 1960) and the opium and heroin trade fell into the hands of his long-time rival.

Therefore, post-war Thailand emerged as a major trafficking corridor for opiates produced either in Burma or, despite Sarit's 1959 ban on opium production, on its own territory. The growing importance of drug trafficking in Thailand was clearly the direct consequence of a combination of several phenomena: on one hand, the deep penetration of the Thai politico-economic system by Teochiu syndicates and their use by the Thai leaders; and on the other hand, the role of the Japanese occupation forces, and the evolution of the role of the KMT, firstly in China, then in Burma and in Thailand. Also, the emergence of a nationalistic and irredentist Thailand during the Second World War allowed the kingdom to play a privileged intermediary's role between the KMT and Japan. This position that Thailand's Teochiu made possible eventually benefited their own networks and those of the Taiwan-based Hokkien; for these two Chinese communities have played a major role in the region's drug trafficking (Chouvy, 2002: 182).

\section{Contemporary drug trafficking routes of mainland Southeast Asia}

Thailand remained the main heroin trafficking route in Southeast Asia until the early 1990s. However, a number of factors have contributed to the reorientation of drug trafficking routes within Southeast Asia and to the development of new routes to other parts of the continent. The Thai crackdown on heroin trafficking that took place after the 1984 nationwide opium eradication campaign considerably reduced the use of its well-developed road system by smugglers and traffickers from the Thai-Burma border. Subsequent patrols of the north and north-western Thai border by the Thai Third Army and the Border Patrol Police 
also disrupted the routes used across the Thai-Burma border by opium and heroin traffickers (Chouvy, 2002: 173-199; Chouvy, 2009; Ko-Lin Chin, 2009).

Yet, since the mid-1990s, the old paths of the former Communist Party of Thailand (CPT) through the mountain range stretching from Chiang Mai to Lampang, as well as outposts of KMT within Thailand (Haw Division 93 for example, in Mae Hong Son province), have been widely used by traffickers mainly carrying methamphetamine. Since 1999, Thai authorities have reacted to these new trends by turning their Internal Security Operations Command (ISOC) from an anachronic and redundant anti-Communist task force to an anti-drugs unit. In the early 2000s, ISOC was used to complete a large defence system made up of the Border Police Patrol (set up by the CIA in the early 1950s), the Third Army ${ }^{7}$, and the National Security Council (Chouvy, 2002d) ${ }^{8}$. In the meantime, the Third Army launched its Territorial Defence Training Scheme, a programme intended to strengthen the Thai-Burma border by arming 592 border villages and training them for self-defence against incursions of armed groups and drug traffickers. In 2001, the Thai government, which hosted the annual Cobra Gold military manoeuvres with the US Army, set up a special fighting force dedicated to counternarcotics operations along the border. Task Force 399, based in Mae Rim (Chiang Mai) and made up of 200 men from the Thai Special Forces and Border Patrol Police, was assisted by 20 instructors from the US Special Forces' $1^{\text {st }}$ Group. Allegedly used by the United States to supply military equipment and covert drug interdiction training to Yawd Serk's SSA-S (opposed to Rangoon and the UWSA), Task Force 399 was dismantled in October 2002 after Rangoon complained about its "provocative actions" and denounced it as an impediment to friendly Thai-Burmese relations (Chouvy, 2009).

The commercial opening of both southern China and northeast India since the mid1980s has also allowed the emergence of new trafficking routes. Heroin trafficking has followed the famed Burma Road since at least 1985, passing through the Burma-China border 
posts of Muse and Ruili and continuing on through Baoshan, a nineteenth century Yunnanese hub of opium trafficking, then through Dali and Kunming (Lintner, 1998: 172; Malik, 1995, Zhou, 1999: 115). Spanning 1,200 km, the Chinese border has been increasingly traversed since Burma's junta legalised cross-border trading in 1986, and since the 1989 fall of the Communist Party of Burma (CPB) and the subsequent appearance of the United Wa State Army (UWSA) ${ }^{9}$ in northern Shan State (Renard, 1996: 62). A decade later, in May 1998, Chinese authorities estimated that at least $100 \mathrm{~kg}$ of heroin transited daily through Bose, in Guangxi province (Chouvy, 2002: 173-199; Chouvy, 2009).

Other drug trafficking routes include those passing through the Kambaiti Pass or, further south, through Loije. From Yunnan, Burmese heroin can then reach eastern China and Hong Kong, to be eventually exported overseas to Australia and North America. However, large quantities of Burmese heroin are also bound for the Southeast Asian market, entering Laos through its Luang Namtha and Phong Saly provinces. China is prone to drug trafficking from Burma since its southern neighbour has an important Chinese population that consists of, among others, Panthay caravan traders, former KMT as well as CPB members, and local Kokang Chinese, all of whom are more or less involved in illicit cross-border activities and drug trafficking. The powerful attraction of both Hong Kong and Taiwan as major international heroin trafficking hubs is also likely to add to the appeal of the Chinese route (Chouvy, 2002; Chouvy, 2009; Ko-lin Chin, Zhang, 2007). According to the results of a rare field study of drug trafficking activities between Burma and China: "Over the past few decades, drug trafficking between Burma and China has evolved in several directions. Shipments of drugs in large quantities have largely disappeared (or perhaps are better concealed) and most drugs are moved in small quantities by large numbers of individuals, or "mules," who know little about the organizers behind the scene. Between drug manufacturers and end users are multiple and often overlapping layers of transportation and distribution 
networks, each involving only a few people. These groups of "mules" and their organizers work much like ants moving the contraband piece by piece successively from one location to another" (Chin, Zhang, 2007: 4). This phenomenon is not restricted to the drug trade between Burma and China: it has also been witnessed between Burma, Thailand, Laos, and India.

While China is certainly the main transhipment destination for heroin from Burma, it is not the only one, as northeast India also draws some of the traffic. From poppy fields in northeast Burma, opium and heroin are transported by road, through Bhamo, Lashio and Mandalay to northeast India, which shares a 1,463 km border with Burma. Heroin trafficking across the India-Burma border was first noticed in the early 1990s, and six heroin laboratories were discovered in western Burma in 1992 (Lintner, 1998: 175). There are two main drug trafficking routes leading from western Burma to the Indian states of Nagaland, Manipur and Mizoram. The foremost route begins in Mandalay, continuing through Monywa and Kalewa, where it splits: northward, to the Tamu-Moreh border crossing and the Indian Road 39, in Manipur; and southward, to Hri-Champhai, into Mizoram (SAIN, 1998; Tarapot, 1997). Further north in Burma, Homalin is reached all the way from Bhamo and serves as a springboard into Nagaland, from where the heroin goes to Assam in India and, through Dispur, joins other shipments bound for Calcutta and the rest of the subcontinent.

However, from Mandalay, Burmese heroin also goes to Rangoon, Burma's capital until 2005 and the country's largest town, either by road or by way of the Irrawaddy River. This upsurge in drug trafficking across the India-Burma border occurred in the context of a thriving contraband economy that has existed around Tamu-Moreh and Hri-Champhai since 1965, despite the fact that cross-border trading was finally legalised in 1995. Political and social instabilities, armed violence linked with autonomous rebellions as well as state repression, and endemic underdevelopment and poverty, make a long and poorly manned 
border prone to drug trafficking as well as the smuggling of precious stones, hard woods (teak), gold and various consumer goods (Tarapot, 1997).

\section{Drug trafficking and the spread of blood-borne diseases}

The existence of drug production in the area known as the Golden Triangle has contributed to the considerable increase in the consumption of opiates among Southeast Asian populations and even farther afield, along all the Asian drug trafficking routes. Consequently, the spread of opiate trafficking and the increase of their consumption led to an epidemic, only slightly later, of HIV/AIDS. The HIV/AIDS outbreak in Asia occurred between 1988 and 1990 and coincided with the multiplication and diversification of the Asian drug trafficking routes - from Southeast Asia as well as from Southwest Asia - and their reorientation towards the north, as well as with the spread of heroin addiction throughout the Asian continent. North of Burma, the Chinese province of Yunnan has not only become the region's main drug trafficking route but also accounted for 80 per cent of all China's HIVpositive individuals in 1990. The area was then awash with Burmese heroin, and two-thirds of the injecting drug users of the Chinese border town of Ruili were HIV positive, as was also the case in Guangxi, the next stop on the traffickers' route (SAIN, 1998). In 2009 Yunnan and Guangxi still ranked among the six Chinese provinces with the most cumulative reported cases (UNAIDS, 2010a).

The correspondence in Yunnan between the development of heroin trafficking, the emergence of intravenous injection - nowadays the main mode of heroin consumption - and the near-simultaneous waves of heroin addiction and HIV/AIDS infection, can now be seen all over Asia. A similar process occurred in northeast India where heroin trafficking from Burma quickly increased. As has happened in China, in the 1990 s 80 per cent of the heroin addicts of Manipur, the main drug trafficking gate, were infected with HIV (SAIN, 1998; Beyrer et al., 2000). Manipur is still the Indian state with the largest HIV/AIDS epidemic, 
where it appears that the disease began to spread at a particularly fast rate after the bilateral Indo-Burmese border agreement came into effect. In 2006 and 2007 Manipur was still the Indian state showing the highest adult HIV prevalence in India, estimated at over 1.5 percent (UNAIDS, 2010b: 18). Apart from law and order issues, the upsurge of heroin addiction and the raging HIV pandemic that have accompanied the development of the drug trafficking routes in southern China and northeast India now constitute one of the main challenges faced by Asia, the second most affected continent by the HIV/AIDS pandemic and the only one where HIV/AIDS first spread through injecting drug use (Beyrer et al., 2000).

\section{"New” routes for a "new" drug}

In the late 1990s, the diversification of drug trafficking routes increased together with the diversification of illicit drug production. The explosion of methamphetamine production in Burma, in which Khun Sa played a significant role (Lintner, Black, 2009: 62, 63), has led to resurgence in the use of the Thai route, since Thailand is by far the most significant consumer market of yaa baa, or methamphetamine. Despite that fact, Burma is still by and far the main producing country of methamphetamine in Southeast Asia (and maybe in the world), with Wei Xuegang ${ }^{10}$, the "de facto financial controller" of the UWSA, being the foremost "merchant of madness", that is, the "heroin kingpin and overlord of most of the methamphetamine production in the Golden Triangle" (Lintner, Black, 2009: 67). The authors of Merchants of Madness actually list 16 major players in the production of and trade in methamphetamine in Burma, from Wei Xuegang to the Bao brothers (Bao Youxiang being the chairman of the United Wa State Party and supreme commander of the United Wa State Army), Bang Ron (allegedly leader of one of Thailand's largest methamphetamine trafficking networks until 1998, when he fled to Burma and linked to Wei Xuegang), and Yawd Serk (commander of the Shan State Army-South, on the Thai border) (Lintner, Black, 2009: 67-89, 149). The strong crackdown led by the Thai army and the police in the early 2000s in the 
northernmost part of the country has temporarily diverted the flux of methamphetamine, pushing traffickers to use new itineraries. Yaa $b a a$, but also heroin, therefore started entering Thailand from Laos through border towns such as Chiang Khong, Nan, Loei, Nong Khai, Nakhon Phanom, Mukdahaern and Ubon Ratchathani. The roads of Laos are frequently used for transporting illicit drugs bound for Thailand, even though drug trafficking aboard speedboats along the Mekong River, which demarcates the international border between the two countries, is the preferred choice. This is exemplified by the February 2009 shootout that took place on the river between Burma's military and Naw Kham, a former soldier of Khun Sa and now leader of the small Hawngleuk militia, who began to levy a protection tax on drug shipments in 2007 as well as extort money from legitimate traders ${ }^{11}$. Since 2004 and the removal of river rapids in Burma and Laos, the Mekong has become a more profitable trading route (despite the construction of the transport corridors' multiple roads for the Greater Mekong Subregion or GMS) between China and Thailand, and as a result China then allegedly put pressure on Burma, Laos and Thailand to stop Naw Kham's extortion practices against Chinese cargo boats. The Thai Office of the Narcotics Control Board (ONCB) estimates that between 3 and 5 million methamphetamine pills enter Thailand from Laos each year $^{12}$, through the numerous villages - such as Ban Ahi, in Laos (50 km north of Loei) from where methamphetamine, locally grown cannabis, and weapons enter Thailand - that straddle the border (Chouvy, Meissonnier, 2004). Police General Krisna Polananta, secretary-general of the ONCB, declared in 2010 that the Mekong had become "a major smuggling route"13.

Further south along the Thai border and lower on the Mekong, Cambodia is also increasingly used as a staging point for trafficking methamphetamine via Trat and Chanthaburi into Thailand. The latest indication that Cambodia is such a staging point occurred in March 20011 when 11 kilogrammes of methamphetamine trafficked from Laos and destined to either Thailand or Vietnam were seized from Vietnamese and Lao nationals 
in Phnom Penh ${ }^{14}$. Cambodia has also long been suspected of producing amphetamines, notably in Koh Kong province (including, reportedly in the late 1990s, on a boat off the coast), where most of country's cannabis used and is still likely to come from ${ }^{15}$. Methamphetamine production evidently developed in the following years as shown by the dismantling of a large laboratory in a cattle ranch in Kampong Speu province in April $2007^{16}$. In another case, in August 2007, Cambodian authorities arrested the leader of a methamphetamine tableting operation in Phnom Penh, where they seized, for the first time in the country, a rotary tableting machine with the capacity of producing 10,000 methamphetamine tablets per hour ${ }^{17}$. East of Laos and Cambodia, Vietnam has similarly been turned into a drug trafficking route, either from or to China. Overseas trafficking is frequently organised from Vietnamese seaports such as Hoi An, Danang, Vinh and Haiphong or from the Cambodian Koh Kong province or Pochentong airport (Phnom Penh). Vietnam is also a destination for Burmese heroin, the Hekou-Lao Cai border crossing being one of the most frequently used. Drug trafficking routes in Southeast Asia are becoming increasingly complex with traffickers constantly diversifying their itineraries, some of them sometimes taking national authorities by surprise.

After the Second World War, Thailand was first avoided by drug traffickers coming from Burma because its police and army, as well as its leaders, were notoriously corrupt and cost the traffickers too much in bribes. Laos was thus originally used to bypass such added taxes. More recently, however, it is the tough anti-drug policy of Thai authorities that has been driving traffickers towards alternative routes such as Laos and Cambodia. In 1999, for example, Thai authorities increased the number of border checkpoints along its Laotian and Cambodian borders from 100 to 269 , again encouraging the traffickers to resort to other routes. 
In recent years, routes through southern Thailand have been on the agenda of both traffickers and anti-drug forces, particularly since March 2000, when several million methamphetamine pills were seized in Prachuap Khiri Khan, having been trafficked from Kawthaung, or Victoria Point, in Burma, to Ranong, Thailand. In January 2001, another seizure confirmed this reorientation of drug trafficking through southern Burma and Thailand. Close to eight million pills and $116 \mathrm{~kg}$ of heroin were seized aboard Thai fishing boats west of the Ko Surin islands, pointing to the Andaman Sea as a major drug route. Allegedly, most ( 80 per cent) of the drugs entering Thailand still come across the northern part of the Thai-Burma border, but the constant strengthening of Thai anti-drug actions has clearly fostered a wide diversification of drug trafficking routes as well as a diminution of the quantity of drugs being transported at any one time (Chouvy, Meissonnier, 2004; Lintner, Black, 2009).

Drug trafficking in mainland Southeast Asia also happens to involve Nigerian or other West African (notably Ghanaian) traffickers. As the US Department of State stated in a 2000 report, "Nigeria remains a worldwide hub of narcotics trafficking and money laundering activity. Nigerian organized criminal groups dominate the African drug trade, and transport narcotics to markets in the United States, Europe, Asia, and Africa"18. Nigerian traffickers often base their heroin trafficking operations in Thailand to ship parcels to the United States or send Thai mules to China. A large-scale Bangkok-based Nigerian-run heroin smuggling ring involved in shipping heroin from Southeast Asia to the United States was dismantled in 1996. At the time, Thomas A. Constantine, administrator of the U.S. Drug Enforcement Agency, declared that the international crackdown "immobilized an important international Nigerian syndicate, based in Bangkok, which smuggled heroin through Europe and Mexico and distributed it to street gangs in the Midwest." Couriers were reportedly sent throughout Thailand and Cambodia to procure the heroin for the Nigerians drug dealers ${ }^{19}$. Nigerian 
traffickers are often arrested in Thailand, Cambodia, Laos, Vietnam, and China. Nigerian mules are regularly arrested on heroin trafficking charges in Cambodia and in Vietnam, sometimes on their way to China, where arrest also happen and where Nigerian traffickers and Thai women used as mules by Nigerian or other West African drug traffickers are often executed ${ }^{20}$.

\section{Drug trafficking in post-2003 Thailand}

Upon taking office in February 2001, Thailand's Prime Minister, Thaksin Shinawatra, vowed to prevent and suppress both drug trafficking and drug consumption within the kingdom. Past efforts to curb the rise of drug trafficking and consumption had failed as methamphetamine had become the country's drug of choice. As Pasuk Phongpaichit explains, one of the consequences had been the fast increase of the prison population: "Over 7 years from 1996 to 2002, Thailand's prison population increased by 250 percent. At the end of this, in Bangkok 70 percent of prison sentences were drug-related. For the whole country the percentage was 53 percent" (Pasuk, 2003). Thailand has long launched public campaigns to reduce demand and the Thai law prescribes the death penalty for carrying category I narcotics (heroin, amphetamine, methamphetamine, ecstasy and LSD, but not cocaine) "for the purpose of disposal" ${ }^{21}$. However, trafficking and consumption of yaa baa kept increasing and, on 1 February 2003, Thaksin launched a nationwide "war on drugs" aimed at making the country drug-free within three months.

Thaksin set the tone of his antidrug campaign when he declared, in his January 28 speech: "Because drug traders are ruthless to our children. So being ruthless back to them is not a big thing [...] It may be necessary to have casualties [...] If there are deaths among traders, it's normal". Pasuk Phongpaichit stresses: "He also quoted a famous saying of a 1950s police chief known to have masterminded several political assassinations: "There is nothing under the sun which the Thai police cannot do" (Pasuk, 2003). The Thai Government 
and the Thai police drew arbitrary lists of drug suspects, establishing a climate of fear that drove intravenous drug users, in particular, underground. In a June 2004 report, Human Rights Watch explains: "the government crackdown has resulted in the unexplained killing of more than 2,000 persons, the arbitrary arrest or blacklisting of several thousand more, and the endorsement of extreme violence by government officials at the highest levels" (Human Rights Watch, 2004: 1). Many of those named on government "blacklists" and "watchlists" had been mistakenly included or reported by personal rivals and many were killed for no reason or for reasons other than related to drug trafficking.

The 2003 Country Reports on Human Rights Practices of the US Department of State faulted the Thai government for the "excessive use" of "lethal force against criminal suspects" and denounced the many "extrajudicial, arbitrary and unlawful killings" that took place during Thailand's war on drugs. The report stated: "According to official figures, there were 1,386 narcotics-related deaths between February 1 and April 30, 2003. No arrests were made in 1,195 of these cases, which led many observers to believe police were responsible for most of these deaths" (US Department of State, 2004: Thailand). To Thailand's human rights activists who blamed the government of unleashing a "shoot to kill" policy and condoning the killings of suspected-only drug dealers, the government replied that many of the killings resulted from dealers fighting each other. The campaign, however, has been popular in Thailand despite the fact that only a few large drug traffickers were arrested and at least a dozen managed to flee to Burma, Laos, or even China.

Most observers agreed on the fact that "the violence unleashed by the Thai government on 1 February 2003 created terror and confusion among drug traders and users, which - not surprisingly - had a genuine impact on the supply of methamphetamines" (Roberts, Trace, Klein, 2004: 7). Some also warned: "the 'ya ba' problem may have - to a certain extent - been temporarily suppressed, but that it has not gone away" (Roberts, Trace, 
Klein, 2004: 7). Human Rights Watch concluded in its report: "The clearest outcome of the war on drugs was not to curb Thailand's illegal drug trade, but simply to make it more dangerous. Most drug users interviewed by Human Rights Watch reported continuing to use heroin or methamphetamines during the drug war, albeit at a higher cost and less frequently" (Human Rights Watch, 2004: 1). In late 2003, the Thai government claimed that the operation had been a "victory beyond expectation". However, after yaa baa seizures increased again in Thailand ${ }^{22}$, Thaksin called for a second war on drugs in October 2004, this time with much less violence and publicity, despite a few heated declarations: "Drug dealers and traffickers are heartless and wicked. All of them must be sent to meet the guardian of hell, so that there will not be any drugs in the country"23. In 2005, methamphetamine was still widely produced in Burma and in the rest of mainland Southeast Asia, where consumption is still developing. Still, in May 2006, a few months before he was ousted by a military junta, a newspaper stated that (on 19 September 2006), "Prime Minister Thaksin Shinawatra has pledged to step up the government's crackdown on drugs following complaints about the reemergence prevalence of drugs in several Bangkok districts" ${ }^{24}$. Thailand's wars on drugs obviously proved less successful at stopping drug trafficking to and within its territory than its thirty years of economic development at eliminating all but its opium production.

In fact, starting in 2009, after a few of Burma's ceasefire groups, including the UWSA, refused to surrender their arms and join a Border Guard Force, tensions have considerably increased between those groups and Burma's junta, which resulted in Thailand witnessing a large surge in drug trafficking. Ceasefire groups are reportedly selling their stocks of heroin and methamphetamine in order to buy weapons and be able to better resist a potential assault by Burma's military. Seizures of both opiates and methamphetamine have considerably increased between 2008 and 2009: more than 2000 per cent for heroin alone ${ }^{25}$. In 2010, the United Nations Office on Drugs and Crime (UNODC) representative in 
Bangkok, Gary Lewis, told reporters that 23 million methamphetamine pills had been seized in Myanmar in 2009, that is, twenty-three times more pills than in 2008. Lewis said that "the greater seizures reflected a rise in production rather than improved interdiction efforts" 26 . According to the $\mathrm{ONCB}$, out of the 26.6 million yaa baa tablets that were seized in Thailand in 2009, almost half were in the final three months of the year, when tensions started to aggravate between the UWSA and Burma's military government ${ }^{27}$. As a consequence, in April 2009 Bangkok launched a new counter-narcotics campaign, the "Five Fences Strategy". Designed to curb trafficking and consumption of illicit drugs in the kingdom, the Border Fence, the Community Fence, the Social Fence, the School Fence, and the Family Fence aim at "controlling drug abusers, drug traffickers, and groups of people who are sensitive to drug abuse (potential drug demand) in order to build up the front line to prevent drugs and control drug problems effectively"28. Also, in August 2009 Thailand quietly revived its former Task Force 399 into a new counter-narcotics force, the $151^{\text {st }}$ Special Warfare Company, deployed along Burma's border ${ }^{29}$.

\section{The build-up of drug control in mainland Southeast Asia}

With the beginning of the twentieth century a major change took place in the way narcotics and other drugs were addressed politically, socially and economically. Until then only the Indian-Chinese opium trade had been targeted by prohibitionists. Then, the United States initiated a global policy aimed at reducing both production and consumption of certain drugs. A long historical process then led to the 1961 Single Convention on Narcotic Drugs, to the 1971 Convention on Psychotropic Substances, and to the 1988 Convention against Illicit Traffic in Narcotic Drugs and Psychotropic Substances, three United Nations conventions that were introduced to help legislate and control the illicit drugs industry worldwide. In 1998, a global strategy to reduce illicit drug supply was adopted during the United Nations General Assembly Special Session (UNGASS) on the World Drug Problem: regional and 
sub-regional mechanisms, as well as stronger bilateral cooperation were called for in order to achieve a "drug-free world" by 2008 .

In 1993, China, Myanmar, Laos, Thailand and the United Nations International Drug Control Programme (precursor to UNODC) signed a Memorandum of Understanding for Drug Control, to which Cambodia and Vietnam became parties in 1995 . At the $33^{\text {rd }}$ Association of Southeast Asian Nations (ASEAN) Ministerial Meeting in Bangkok in 2000, ministers "took note of the threat from drug abuse and drug trafficking on the security and stability of the ASEAN region, particularly its relations with transnational crime" and called for a drug-free ASEAN by 2015. As a result, a regional framework called ASEAN and China Cooperative Operations in Response to Dangerous Drugs, or ACCORD, was launched. The commitment towards Drug-Free ASEAN 2015 gave the region a clear objective while the ACCORD Plan of Action outlined a road map towards that objective, yet without specifying expected outcomes or providing an ad-hoc menu of quantitative benchmarks. The fact that the United Nations had clearly failed to achieve a "drug-free world" by 2008 (as planned in 1998) obviously did not deter the Southeast Asian nations to set their own unrealistic goal of obtaining a drug-free Southeast Asia. In fact, as the 2008 mid-term progress report produced by UNODC and ASEAN makes clear, the drug-free ASEAN goal was set without even defining what drug-free meant, therefore making any progress toward such a goal impossible to identify (UNODC - ASEAN, 2008: 5-6). Yet, while the same report acknowledges this, it also states that "the commitment of achieving a Drug-Free ASEAN by 2015 is still valid", despite the fact that "the threat of a significant increase in the traffic of drugs due to the devolvement of infrastructure in the GMS and the implementation of trade facilitation agreements across ASEAN is significant" (UNODC - ASEAN, 2008: 85).

Regional response plans that include specific interventions in key areas have been devised in order to counter drug trafficking in the region. ACCORD is the regional 
framework set up to achieve such a goal. The operational arms of the ACCORD Plan of Action are four task forces, one for each pillar of action: the promotion of civic awareness ("advocating on the dangers of drugs"), the reduction of consumption ("by building consensus and sharing best practices in demand reduction"), the strengthening of the rule of law ("improved law enforcement cooperation"), and the elimination or significant reduction of production ("by boosting alternative development projects"). The ACCORD Task Forces meet annually to foster operational coordination through the creation of annual work plans involving the various national level drug control agencies: the Burmese Central Committee for Drug Abuse Control (CCDAC, established in 1975), the Cambodian National Authority for Combating Drugs (NACD, established in 1995), the Lao National Commission for Drug Control and Supervision (LCDC, established in 2001), the Malaysian National Anti-Drugs Agency (NADA, established in 1996), the Singaporean Central Narcotics Bureau (CNB, established in 1971), the Thai Office of the Narcotics Control Board (ONCB, established in 1976), the Vietnamese Standing Office for Drug Control (SODC, established in 2000), and their other regional counterparts.

Cross-border cooperation, mutual legal assistance and supply reduction are of course major objectives in order to achieve the goal of a drug-free ASEAN. UNODC has helped facilitate cross border cooperation via the Border Liaison Offices (BLO) mechanism. As explained in the 2008 ASEAN-UNODC mid-term report, "BLOs bring together law enforcement units from both sides of a land or water border and put in place protocols for joint operations" (UNODC - ASEAN, 2008: 77). As of February 2009, 70 BLOs had been established along the borders of Burma (8), Cambodia (11), Lao PDR (18), Thailand (18), Vietnam (8), and China (7) (UNODC, 2010: 12). India and Malaysia are not part of the BLO programme. According to UNODC, it is in the context of the BLO programme that Lao PDR and Thailand undertook the first joint patrols on the Mekong River in 2003. BLOs keep being 
expanded and strengthened as they are seen by some as the premier method to enhance regional cooperation against drug trafficking, although it seems that BLOs are often far less efficient or useful than what can be expected from stated goals. Visits to a few of the BLOs dotting the Cambodian border (along the Thai, Lao, and Vietnamese borders) revealed an extreme lack of material means, barely existent cross border cooperation, and lack or absence of staff.

While national governments, ASEAN and UNODC have made efforts against drug trafficking, no significant achievement will be reached without addressing illicit drug production in the region, mostly by addressing poverty, that is, the main driver of opium production, whether in Burma or in Afghanistan (Chouvy, 2009). Corruption is also a key issue to be addressed by the ASEAN countries and by UNODC, a topic that their abovementioned common mid-term report conveniently avoids. Yet, Burma ranks among the world's most corrupt countries, as Transparency International, which describes itself as a "global civil society organisation leading the fight against corruption", reported in its yearly reports over the last decade. In 2009, only Afghanistan and Somalia were perceived as being more corrupt than Burma $\left(178^{\text {st }}\right.$ most corrupt country out of 180). Laos ranked 158 along with Cambodia, while Vietnam ranked 120, and Thailand 84, along with India. China fared a bit better as the world's $79^{\text {th }}$ most corrupt country. On the other end, Singapore was ranked as the world's third least corrupt country, well ahead of, for the sake of comparison, the United Kingdom $\left(17^{\text {th }}\right)$, the United States of America $\left(19^{\text {th }}\right)$, or France $\left(24^{\text {th }}\right)^{30}$. It is obvious that corruption hinders counter-narcotics efforts at various levels and especially at the trafficking stage. The proceeds of the illegal drug economy clearly feed corruption, as Willem van Schendel and Itty Abraham suggest when they describe how "the act of enforcing a selected flow of people and objects across a border, from border patrols to customs, immediately allows for the possibility of rents to be charged for circumventing these rules and by the same 
token provides opportunities for smuggling of people and objects across these borders" (Schendel (van), Abraham, 2000). The difficulty of coping with drug trafficking therefore results not only from poverty - which makes drug production and trafficking even more attractive economically - but also corruption. Indeed, a lack of resources and fragile domestic institutions also undermine the efforts carried against both drug production and drug trafficking.

Drug trafficking is only one aspect of the drug economy and while the goals of a drugfree world or a drug-free ASEAN will never be reached, efforts can and should be made to minimise the harm caused by illegal drug production, trafficking, and consumption. Alongside demand reduction, harm-reduction policies, that is, the public health policies designed to reduce the harmful consequences associated with drug use and abuse, are of course a crucial tool against the spread of blood-borne diseases, notably along drug trafficking routes. On the other end, economic development is needed in order to provide alternative livelihoods to opium poppy cultivators: poverty, and more precisely food insecurity, is the main driver of opium production in mainland Southeast Asia. Nevertheless, economic development is not achievable without good governance; that is, without peace, political stability, the rule of law, and control of corruption.

\section{Bibliography}

Beyrer, Chris, Myat Htoo Razak, Khomdon Lisam, Jie Chen, Wei Lui, and Xiao Fang Yu, 'Overland heroin trafficking routes and HIV 1 spread in South and South East Asia', AIDS Vol. 14, No. 1 (2000), pp. 75-83

Booth, Martin, Opium: A History (New York: St. Martin’s Press, 1989)

Chouvy, Pierre Arnaud, Les territoires de l'opium. Conflits et trafic du Triangle d'Or et du Croissant d'Or

(Geneva : Olizane 2002) 
Chouvy, Pierre-Arnaud, Opium: Uncovering the Politics of the Poppy (London: I.B. Tauris Cambridge: Harvard University Press: 2010 / 2011)

Chouvy, Pierre-Arnaud and Meissonnier, Joël, Yaa Baa : Production, Traffic, and Consumption of Methamphetamine in Mainland Southeast Asia (Singapore: Singapore University Press 2004) Frey, Robert and Lintner, Bertil, 'Jade in Burma: The Major Jadeite Source. The Jade Trade in Burma', in Keverne, Roger, Jade (London: Lorenz Books, 1995), pp. 266-271

Human Rights Watch, 'Not Enough Graves, The War on Drugs, HIV/Aids, and Violations of Human Rights' Human Rights Watch Report Vol. 18 No. 8 (June 2004)

Motohiro Kobayashi, 'Drug Operations by Resident Japanese Tianjin', in Brook, Timothy and Wakabayashi, Bob T., Opium Regimes, China, Britain, and Japan, 1839-1952 (Berkeley: University of California Press, 2000), pp. 152-166

Ko-Lin Chin, The Golden Triangle. Inside Southeast Asia’s Drug Trade (Ithaca/London: Cornell University Press, 2009)

Ko-Lin Chin, Sheldon X. Zhang, 'The Chinese Connection: Cross-border Drug Trafficking Between Myanmar and China', in Final report to the United States Department of Justice (unpublished) National Criminal Justice Reference Service (April 2007)

Kramer, Tom, 'The United Wa State Party: Narco Army or Ethnic Nationalist Party?', East-West Center Policy Studies No.38 (2007)

Levy, Adrian and Clark, Cathy S., The Stone of Heaven. The Secret History of Imperial Green Jade (Londres: Phoenix, 2002)

Lintner, Bertil, Burma in Revolt: Opium and Insurgency since 1948 (Boulder: Westview Press, 1994)

Lintner, Bertil, 'Drugs and Economic Growth, Ethnicity and Exports' in Rotberg, R.I. (ed) Burma, Prospects for a Democratic Future (Cambridge / Washington: The World Peace Foundation / Harvard Institute for International Development / Brookings Institution Press, 1998) pp. 165-183

Lintner, Bertil and Black, Michael, Merchants of Madness. The Methamphetamine Explosion in the Golden Triangle (Chiang Mai: Silkworm Books, 2009)

Malik, J. Mohan, 'China-India relations in the post Soviet era: the continuing rivalry', The China Quarterly No.142 (June 1995), pp. 317-355

McCoy, Alfred W., The Politics of Heroin. CIA Complicity in the Global Drug Trade (New York: Lawrence Hill Books, 1991) 
McCoy, Alfred W., The Politics of Heroin. CIA Complicity in the Global Drug Trade (Afghanistan, Southeast

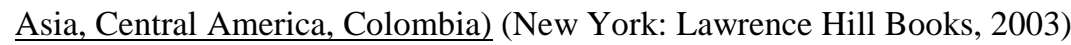

Meyer, Kathryn and Parssinen, Terry, Webs of Smoke. Smugglers, Warlords, Spies, and the History of the International Drug Trade (Lanham: Rowman \& Littlefield 1998)

Milsom, Jeremy, 'The Long Hard Road Out of Drugs: The Case of the Wa', in Jelsma, M., Kramer, T., Vervest P., (eds), Trouble in the Triangle. Opium and Conflict in Burma, (Chiang Mai: Silkworm Books, 2005) pp. 61-93

Mya Maung, The Burma Road to Poverty (New York: Praeger Publishers 1991)

Pasuk Phongpaichit, 'Drug policy in Thailand' First International Symposium on Global Drug Policy, Senlis Council, Lisbon, 23-25 October 2003

Renard, Ronald D., 'The Burmese Connection. Illegal drugs and the making of the Golden Triangle' Studies on the Impact of the Illegal Drug Trade, Vol. 6 (Boulder-London: Lynne Rienner Publishers 1996)

Roberts, Marcus, Trace, Mike and Klein, Axel, 'Thailand's 'War on Drugs'” Drugscope Briefing Paper, No.5

(Drug Policy Programme, Beckley Foundation 2004)

SAIN (Southeast Asian Information Network), Out of Control. The HIV/AIDS Epidemic in Burma. A Report on

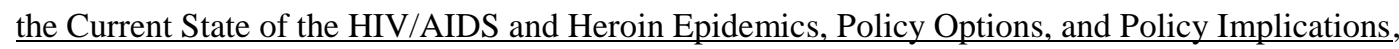

(Chiang Mai 1998)

Schendel, Willem van and Abraham, Itty Beyond Borders: (Il)licit Flows of Objects, People, and Ideas, Social Science Research Council, Discussion Paper (New York, 2000)

Seagrave, Sterling, Lords of the Rim, The Invisible Empire of the Overseas Chinese, (London: Corgi Books, 1995)

Smith, Martin, Burma: Insurgency and the Politics of Ethnicity (London: Zed Books, 1991)

Tarapot, Phanjoubam, Drug Abuse and Illicit Trafficking in North Eastern India (New Delhi: Vikas Publishing House, 1997)

UNAIDS (United Nations Programme on HIV/AIDS), 2009 Estimates for the HIV/AIDS Epidemic in China (Beijing: UNAIDS, 2010a).

UNAIDS, UNGASS Country Progress Report 2009 (New Delhi: UNAIDS, 2010b)

UNODC (United Nations Office on Drugs and Crime), Border Liaison Offices in Southeast Asia 1999-2009

(Bangkok, UNODC, 2010) 
United States Department of State, International Narcotics Control Strategy Report 2003 (Bureau of

International Narcotics and Law Enforcement Affairs, US Department of State, March 2004)

Walker, Anthony R., 'The Production and Use of Opium in the Northern Thai Uplands: An Introduction',

Contemporary Southeast Asia, Vol. 2 No.2 (September 1980), pp. 135-154

Yongming,Zhou, Anti-Drug Crusades in Twentieth-Century China. Nationalism, History, and State Building,

(Lanham: Rowman \& Littlefield, 1999)

\footnotetext{
${ }^{1}$ The Karen National Union (KNU) has fought Burma's central government since the country's independence, in 1948.

${ }^{2}$ The Kuomintang (KMT), Chiang Kai-shek's Chinese nationalist troops who fought and lost against the People's Liberation Army (PLA) of the Chinese Communists, was going to deeply affect opium production in mainland Southeast Asia (Chouvy, 2009).

${ }^{3}$ Opium production and trade developed all the more easily after Ne Win set up the Ka Kwe Ye (KKY), or selfdefence groups, whose mission and role was to second the government and the Armed Forces (Tatmadaw) in their combat against the rebels. Ne Win had tacitly authorized the KKY to engage in all types of business and trade, including the most profitable activity to be found in the mountainous peripheral regions where the KKY were to restore law and order: opium and heroin trafficking. Among the sixty or so KKY, which quickly constituted, the two most important were both headed by half-Chinese half-Shan chiefs: Lo Hsing-han and Chan Shi-fu, alias Khun Sa (Lintner, 1994; McCoy, 2003; Smith, 1991). Chan Shi-fu, "stepson of the ruler of Loimaw (one of the northernmost Shan principalities)" (Renard, 1996: 60), took advantage of the opportunity which was offered to him with the creation of the KKY and recycled his own militia. Investing himself in the opium business, he was quickly betrayed by the Shan nationalists with whom he had negotiated passage rights for his opium caravans and only began effectively fighting them in 1966: three years after he should have done so as a KKY leader supposedly at Ne Win's service. In the context of ceaseless internecine feuds largely sparked by the very competitive opium business, Rangoon abolished the KKY in 1973. However, during the ten years that the KKY existed, Chan Shi-fu, self-dubbed “opium king”, and Lo Hsing-han, became the Golden Triangle's two most powerful opium traffickers.

${ }^{4}$ Cantonese pronunciation of Teochiu, largely used by the police and press of Hong Kong where many Teochiu are strategically settled.

${ }^{5}$ The Hokkien are mainly based in Taiwan, Singapore, Malaysia, the Philippines, and Indonesia.

${ }^{6}$ Father of Chatichai Choonhavan, Foreign Minister between 1975 and 1976, and democratically-elected Prime Minister of Thailand between 1988 and 1991.

${ }^{7}$ In Thailand, opium poppy eradication is still conducted every year. In 2006, out of 157 cultivated hectares, 153 were eradicated (97 per cent). The Thai case illustrates how the war on drugs translates into the militarization of counternarcotics operations as the Third Army and the Border Patrol Police respectively conducted 77 per cent and 10 per cent of the total eradication in the country (UNODC, 2006d: 127).

${ }^{8}$ After the 2006 military coup d'état established the Council for National Security (CNS) to rule over the country, ISOC was turned into something akin to the US Department of Homeland Security.

${ }^{9}$ The UWSA has sensationally been dubbed "the world's largest drug trafficking army" by the US Department of State and, in January 2005, the US Department of Justice indicted eight senior leaders of the United Wa State Party/UWSA for belonging to a "powerful criminal syndicate and worldwide narcotics trafficking organization" and notably "importing over a ton of heroin with a retail value of 1 billion US dollars into the United States alone. The UWSA now claims to have suppressed opium production from Special Region $\mathrm{N}^{\mathrm{o}} 2$, something attested by UNODC, and argues, along with the Burmese authorities, that methamphetamine production in the region is largely in the hands of Chinese manufacturers and syndicates (Kramer, 2007; Milsom, 2005: 76-77).
} 
${ }^{10}$ Wei Xuegang was born in Yunnan in 1946 and is a former KMT soldier who allied himself to Khun Sa until he joined forces with the UWSA in 1989. In 1996 he was appointed a member of the central committee of the United Wa State Party and was given command of the conveniently located army's 171 Military Region near the Thai border. Since 2002 he lives in a US\$30 million fortified complex in Nalawt, outside of Panghsang, the UWSA's Special region $N^{\circ} 2$ capital (Lintner, Black, 2009: 67).

${ }^{11}$ McCartan B., 'Manhunt is on for Mekong Robin Hood', Asia Times, 7 April 2009

${ }^{12}$ McCartan B., 'Drugs, guns and war in Myanmar', Asia Times, 4 November 2009

13 'Tracking Down the Traffickers', Bangkok Post, 18 April 2010

14 'Cambodia charges six foreigners for drugs', Strait Times, 15 March 2011.

15 'Cambodge : Il y a quelque chose de pourri au royaume du Kampuchea', Dépêche international des drogues, $\mathrm{n}^{\circ}$ 91, mai $1999: 1,3-4$

${ }^{16}$ No drugs were found on the premises, but the Cambodian National Authority for Combating Drugs (NACD) identified chemicals used in the two-stage process of manufacturing methamphetamine, known as the "Emde Process": 'Cambodia: Methamphetamine usage rising', IRIN Asia, 21 August 2008.

${ }^{17}$ Ibid.

${ }^{18} 2000$ International Narcotics Control Strategy Report, US Department of State, March 2001: http://www.state.gov/p/inl/rls/nrcrpt/2000/index.htm (Nigeria chapter).

19 'U.S. Leads Sweep of Global Heroin Smuggling Ring', Los Angeles Times, 12 October 1996.

20 'Nigerians face drug trafficking charges in Vietnam', Daily Times of Nigeria, 5 April 2011; 'Nigerian sentenced to death for drug dealing', China Daily, 11 March 2010; 'Nigerian heroin traffickers convicted', Phnom Penh Post, 16 February 2011; 'A one-way ticket to trouble', Bangkok Post, 6 February 2011.

${ }^{21}$ On 24 August 2009, two drug traffickers were given the capital punishment in Thailand for having been arrested in 2001 with 114,219 methamphetamine tablets in their possession. The Thai government reported that as of August 2010, there were 339 people on death row for drug-related offences. See: Thailand's Narcotics Act (Given on the $22^{\text {nd }}$ day of April B.E. 2522 (1979)) on www.aseansec.org (http://tinyurl.com/68n4j8e), and the International Harm Reduction Association report on "Human rights violations associated with Thailand's anti-drug laws" (http://www.ihra.net/files/2011/03/14/Thailand.final.pdf). 22 'Meth Still Pouring in to Thailand', Bangkok Post, 26 September 2004

23 'Thaksin Declares New Drug War', Bangkok Post, 4 October 2004

24 'Thaksin to Revitalise War on Drugs', Bangkok Post, 19 May 2006

25 'Myanmar Drug Trade Surges Along Thai Border', New York Times, 1 October 2009.

26 'Holes in Thailand's drug fences', Asia Times, 13 July 2010

27 'Tracking Down the Traffickers', Bangkok Post, 18 April 2010

${ }^{28}$ Office of the Narcotics Control Board, 'National Narcotics Control Policy on Five Fences Strategy': http://en.oncb.go.th/document/e1-info-5Fence.html (Consulted on 12 July 2010)

${ }^{29}$ McCartan B., 2009, 'Drugs, guns and war in Myanmar', Asia Times, 4 November 2009

${ }^{30}$ Transparency International, Corruption Perception Index 2009 : http://www.transparency.org/policy_research/surveys_indices/cpi/2009/cpi_2009_table (consulted on 12 May 2010) 